\title{
КОРОТКИЙ НАРИС ЖИТТЕВОГО ТА ТВОРЧОГО ШЛЯХУ ПРОФЕСОРА РОМАНА МИХАЙЛОВИЧА ПІНЯЖКА (ДО 90-РІЧЧЯ ВІД ДНЯ НАРОДЖЕННЯ)
}

\author{
Думки, виступи, вчинки Романа Михайловича \\ завжди відбивали головне: \\ що слід робити, щоб фрармація розвивалася, \\ щоб справа йшла на лад \\ і щоб кожний з нас був кращим у майбутньому.
} Профресор I. М. Перцев

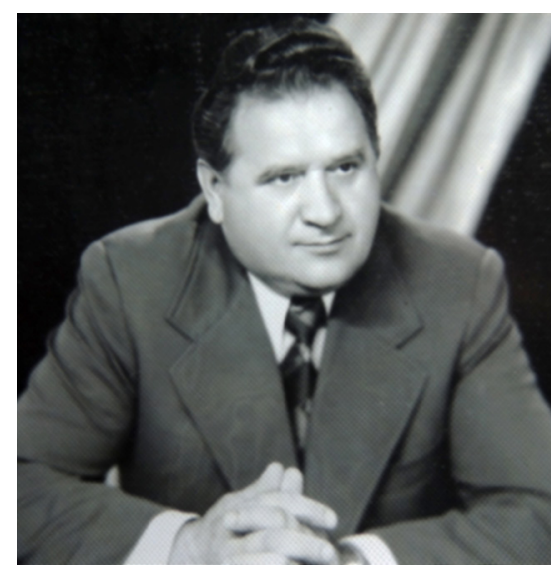

Доктор фрармацевтичних наук, професер Р. М. Піняжко (1928-1983)

Науковій і практичній фрармацевтичній громадськості України та сусідніх держав добре відоме славне ім'я профресора Романа Михайловича Піняжка, якому належить істотний системний і стратегічний внесок у фрормування та розвиток однієї з найважливіших фрармацевтичних наукових дисциплін - організації та економіки фрармації. На думку ректора Львівського національного медичного університету імені Данила Галицького, академіка НАMH України Б. С. Зіменковського, «до найвидатніших представників української фрармацевтичної науки й практики другої половини $\mathrm{XX}$ століття з повним правом можна віднести професора, доктора фрармацевтичних наук Романа Михайловича Піняжка».

Роман Михайлович народився 14 лютого 1928 р. у Глинянах - у чудовому стародавньому містечку, яке знаходиться в центральній частині Гологоро-Кременецького кряжу, неподалік від міста Золочева, що на Львівщині. Тут пройшло його дитинство. Він любив цей край, із захопленням повідав про нього, часто навертався до батьківської домівки й при нагоді запрошував своїх друзів до рідного містечка. Дитинство і юність Романа Михайловича припали на важкі 1930 - 40 рр. Він навчався у Глинянській школі, а також у гімназії Малої Семінарії Греко-Католицької Богословської академії (м. Львів). Як гімназист він отримав архіпастирське благословення Митрополита Андрея Шептицького.
Доля Романа Михайловича тісно пов'язана з фрармацевтичним фракультетом Львівського державного медичного інституту (тепер Львівський національний медичний університет імені Данила Галицького), після закінчення якого він упродовж 1951 - 54 рр. працював начальником Дорожної контрольно-аналітичної лабораторії «Дортранспостачторгу» Львівської залізниці.

У 1954 р. Р. М. Піняжко вступає в аспірантуру при кафедрі технології лікарських фрорм і галенових препаратів Львівського державного медичного інституту, навчання в якій під керівництвом доц. Г. О. Карпенка і проф. М. М. Туркевича успішно завершується захистом у 1958 р. кандидатської дисертаційної роботи «Дослідження стабільності пеніциліну і антибіотиків тетрациклінового ряду» у Московському фрармацевтичному інституті. Отримані Романом Михайловичем результати щодо стабільності антибіотиків мали важливе значення для медицини й фрармації. Його публікації з цього питання неодноразово цитувались у наукових виданнях і наводились у підручниках із орармацевтичної технології.

Після закінчення аспірантури Р. М. Піняжко упродовж 1957 - 68 рр. працював на кафредрах загальної та неорганічної, біологічної, токсикологічної та аналітичної хімії. У 1964 р. Романові Михайловичу присвоєно вчене звання доцента.

Для виконання дисертації на здобуття наукового ступеня доктора фрармацевтичних наук Р. М. Піняжко обирає новий напрямок досліджень - застосування фротометричних методів у фрармацевтичному аналізі. У 1966 р. у 1-му Московському медичному інституті імені І. М. Сєченова він успішно захищає докторську роботу «Дослідження в галузі використання УФ-спектрофротометрії у фрармацевтичному аналізі», виконану за наукового консультування профресорів М. М. Туркевича і В. П. Крамаренка.

Дослідження Романа Михайловича того періоду були присвячені аналізу лікарських засобів - похідних піридину і продуктів його гідрування, ізохіноліну, хіноліну і срентіазину, а також багатокомпонентних лікарських засобів без розділення інгредієнтів. Останній напрямок був піонерським у фармацевтич-

ISSN 2312-0967. Pharmaceutical review. 2018. № 1 
ному аналізі і дав поштовх до розвитку багатохвильової спектрофротометрії.

у 1976 р. Роман Михайлович спільно 3 профр. Т. Г. Калинюком опублікував монографрію «Методи УФ-спектрофротометрії у фрармацевтичному аналізі» (Київ : Здоров'я, 1976).

З 1968 р. Р. М. Піняжко очолює кафедру економіки і організації фрармацевтичної справи, утворену в 1964 р. під керівництвом доц. С. Л. Воскобойник. Саме на цій кафедрі повною мірою проявився організаційний хист, науковий і педагогічний талант Романа Михайловича. Кафредра була однією з перших у країні, на якій викладали фрармацевтичні дисципліни управлінсько-економічного спрямування. У 1969 р. Роману Михайловичу присвоєно вчене звання проdpecopa.

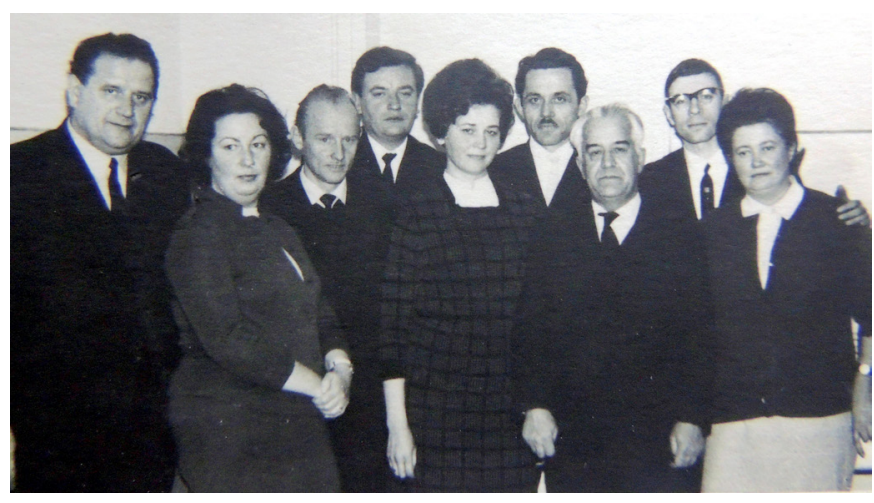

Колектив кафредри, 1971 р. Зліва направо: Р. М. Піняжко Н. І. Сінгалевич, П. Д. Кураш, О. М. Ривак,

Л. Хімка, Є. В. Дасюк, О. С. Мацяк, Б. Л. Парновський, А. М. Новікевич

За весь період керівництва кафедрою Р. М. Піняжко багато зробив для ії становлення, покращення матеріально-технічного оснащення, підготовки наукових кадрів та удосконалення навчального процесу. Завдяки його старанням наприкінці 1971 р. кафедра отримує навчальні приміщення на другому поверсі новозбудованого теоретичного корпусу, обладнується функціональними меблями, аудіовізуальними засобами. 3 метою впровадження обчислювальної техніки у фармацію у науковій лабораторії кафедри була встановлена малогабаритна електронно-обчислювальна машина «Промінь 2М», напевно, одна із перших у галузі (це був кінець 1960-х рр.), яка дозволяла проводити розрахунки прогнозованих показників торгово-срінансової діяльності аптек та визначення потреби у лікарських засобах.

Багатогранною є й наукова спадщина Романа Михайловича. Він дбав про підготовку науково-педагогічних кадрів. Для цього умів своїх учнів зацікавити темою, повірити в неї. Вчив працювати систематично та регулярно звітувати керівникові про зроблене. Ерудиція, дослідницький талант, відчуття нового, сміливість у постановці та вирішенні наукових проблем - ось характерні риси його діяльності як ученого.
Учень Романа Михайловича, проф. Б. Л. Парновський, згадує: «Пам'ятаю, його улюбленим інструментом наукового процесу була дискусія. Уважно слухав, поважав позицію опонента. Не раз повертався до обговорюваної проблеми».

Серед основних напрямків досліджень були: прогнозування шляхів розвитку організації фрармацевтичної справи та фрармацевтичної освіти, опрацювання автоматизованих систем управління в охороні здоров'я і фрармації, спеціалізація аптек і рентабельність аптечних закладів, обґрунтування ідеї консолідації клінічної, промислової та аптечної фрармації, визначення потреби в лікарських засобах, удосконалення роботи промислових підприємств і контрольно-аналітичних лабораторій.

За участі Романа Михайловича у співавторстві 3 І. Т. Корчинським, П. Д. Курашем, А. М. Новікевич та Н. І. Сінгалевич уперше на той час здійснено систематизацію нормативних документів із фрармацевтичної практики у вигляді довідника «Збірник керівних документів 3 організації фрармацевтичної справи» (Львів, 1970).

Під керівництвом Романа Михайловича упродовж 1970 - 80 рр. захищають дисертації на здобуття наукового ступеня кандидата фрармацевтичних наук І. Т. Корчинський (співкерівник - профр. М. М. Туркевич), П. Д. Кураш (співкерівник - доц. С. Л. Воскобойник), А. М. Новікевич, Б. Л. Парновський, О. М. Ривак, Л. С. Торопова, Н. О. Янішевська, В. С. Комар, л. В. Чумакова, А. Й. Дацко, Г. М. Андріанова, Т. С. Райкова. Успішно виконується і захищається дисертація на здобуття наукового ступеня доктора фармацевтичних наук Б. Л. Парновським, результати якої пізніше лягли в основу нового наукового, практичного та освітнього напрямку - фрармацевтичної інформатики. Наслідком співпраці Р. М. Піняжка і Б. Л. Парновського стала перша на теренах країни монографрія «Питання фрармацевтичної інформації» (Москва: Медицина, 1979).

Важливу роль відіграв проф. Р. М. Піняжко у розвитку дидактики фрармацевтичної освіти, насамперед фрармацевтичних дисциплін управлінсько-економічного спрямування. При безпосередній його участі упродовж 1970-х рр. на кафредрі впроваджено дослідницькі методи у навчальному процесі, кабінетну фрорму навчання, тестовий контроль знань, індивідуальні наскрізні завдання щодо прогнозування показників торгово-фрінансового плану аптечних закладів, навчально-методичні фрільми, виробничу документацію, типові форми звіту з практики, збірники нормативних матеріалів. Високий авторитет, професійна ерудиція, великий практичний і життєвий досвід проср. Р. М. Піняжка сприяли формуванню кафедри як провідного наукового та освітнього центру з організації та економіки фрармації.

На думку Романа Михайловича завжди зважали при визначенні змісту фрармацевтичної освіти. Він

ISSN 2312-0967. Фармацевтичний часопис. 2018. № 1 
спільно з професорами В. І. Прокопишиним і В. І. Кріковим обґрунтував доцільність введення на випускному курсі підготовки провізорів спеціалізації, в межах якої з 1978 р. викладалась дисципліна «Основи і методи управління у фармації». Досвід викладання цієї дисципліни Р. М. Піняжко використав при підготовці однойменного навчального посібника (Київ : Вища школа, 1986) у співавторстві з Б. Л. Парновським, О. Л. Громом і А. Й. Дацком, який за ідеологією, структурою та змістом матеріалу став базово-фрормуючим для подальших навчальних видань із менеджменту у фрармації.

Профр. Р. М. Піняжка неодноразово обирали членом правління наукових товариств фрармацевтів різних рівнів, він входив до складу методичного кабінету з вищої фрармацевтичної освіти, проблемної комісії «Фармація» центральних органів виконавчої влади, спеціалізованих учених рад, редакційних колегій журналів.

Роман Михайлович був чуйним чоловіком і люблячим татом. Уже в студентські роки він знайшов своє єдине кохання - Надію Іванівну (провізора за фрахом). Подружжя Піняжків виростило і виховало сина Олега, який став доктором медичних наук, професо- ром, завідувачем кафедри фрармакології Львівського національного медичного університету імені Данила Галицького. Ростуть два внуки. Їх успіхам, безумовно, радів би дідусь.

10 червня 1983 р., на 56 році життя, передчасно перестало битися серце славного подвижника фрармації - профресора Романа Михайловича Піняжка. Більш ніж 35 років з нами немає відомого науковця і педагога, але час не владний над людською пам'яттю.

За словами доц. Р. М. Гулька, «він був люблячий син, щирий українець, вірний християнин, що душею відпочивав неподалік старовинної дерев'яної церкви Успіння Пресвятої Богородиці. В Глинянах у батьківській хаті, в якій, як світлий спомин про батьків, він залишив усе, як було: образи і фотографрії, верети і вишиванки, меблі і підсвічники, які й зараз запалюють на свята, але тепер уже його онуки. Свіча життя горить далі...».

Учні, колеги й друзі, випускники фрармацевтичного фракультету пам'ятають Романа Михайловича як різностороннього вченого і талановитого організатора, чуйного товариша і порадника, як прекрасний зразок служіння фрармації, як патріота України. Пам'ятають про нього, бо він цього заслужив!

Б. П. Громовик, А. Й. Дацко, Т. Г. Калинюк

ISSN 2312-0967. Pharmaceutical review. 2018. № 1 